\title{
KENDALI PERLATAN LISTRIK JARAK JAUH MENGGUNAKAN PROTOKOL TCP/IP
}

\author{
Sunanto $^{1}$, Mas'hum Abdul Jabar ${ }^{2}$ \\ ${ }^{1}$ Fakultas Ilmu Komputer, Universitas Muhammadiyah Riau \\ ${ }^{2}$ Teknik Informatika, Politeknik Kampar \\ ${ }^{1}$ Email: sunanto@umri.ac.id \\ 2Email: M_aje@gmail.com
}

\begin{abstract}
The current control system has developed very rapidly with the existence of microcontroller technology, other electrical and electronic equipment can be controlled automatically. With the development of the internet which is supported by many control devices, making remote control can be done anywhere and anytime as long as it has internet access to the device even though the location of the equipment is quite far away. Utilization of the TCP / IP protocol (Transmission Control Protocol / Internet Protocol) as a network communication media can be applied to control systems connected to electrical circuits, both at home, shops, industries and public facilities. The need for remote control of household electricity is made to provide convenience in controlling electrical equipment, in addition to reducing the risk of harm that may occur when leaving the equipment on. This remote control uses the TCP / IP protocol found on Ethernet Shield devices. Whereas, to make a program or application the Sketch programming language software is needed. This remote control system is equipped with a web server service that can be accessed by users, where this server will be connected to a series of electrical equipment in the household.
\end{abstract}

Keywords: Remote control, housed electricity, TCP/IP, Ethernet Shield

\begin{abstract}
Abstrak
Sistem kontrol saat ini telah berkembang sangat pesat dengan adanya teknologi microcontroller, peralatan listrik dan elektronik lainnya dapat dikontrol secara otomatis. Dengan perkembangan internet yang didukung oleh banyak perangkat kontrol, menjadikan kontrol jarak jauh dapat dilakukan dari mana saja dan kapan saja selama memiliki akses internet terhadap perangkat meskipun letak peralatan tersebut cukup jauh. Pemanfaatan protokol TCP/IP (Transmission Control Protocol/Internet Protocol) sebagai media komunikasi jaringan dapat diterapkan pada sistem kontrol yang terhubung pada rangkaian listrik, baik pada rumah, pertokoan, industri dan fasilitas umum. Kebutuhan pengontrolan jarak jauh pada listrik rumah tangga dibuat untuk memberikan kemudahan dalam mengontrol peralatan listrik, selain itu untuk mengurangi resiko bahaya yang mungkin terjadi ketika meninggalkan peralatan dalam keadaan menyala. Kontrol jarak jauh ini menggunakan protokol TCP/IP yang terdapat pada perangkat Ethernet Shield. Sedangkan, untuk membuat program atau aplikasi dibutuhkan perangkat lunak bahasa pemrograman Sketch. Sistem kontrol jauh ini dilengkapi dengan layanan web server yang dapat diakses oleh pengguna, dimana server ini akan dihubungkan pada rangkaian peralatan listrik yang ada di rumah tangga.
\end{abstract}

Keywords: Kontrol jarak jauh, listrik rumah tangga, TCP/IP, Ethernet Shield

\section{PENDAHULUAN}

Listrik merupakan energi yang paling

banyak dipakai oleh masyarakat sebagai sumber tenaga bagi peralatan elektronik. Sedangkan menurut (Wahid, n.d.) Energi listrik merupakan salah satu kebutuhan masyarakat yang sangat penting dan sebagai sumber daya ekonomis yang paling utama yang dibutuhkan dalam berbagai kegiatan.
Energi ini banyak digunakan oleh rumah tangga, pertokoan, gedung perkantoran, industri perhotelan, pabrik, industri entertainment, penerangan jalan, traffic light, serta kebutuhan sumber daya pada moda transportasi. Dengan adanya listrik, masyarakat dapat merasakan kemudahan dan manfaat yang besar dalam kehidupan seharihari. Namun dibalik manfaatnya, listrik 
menyimpan risiko yang dapat menimbulkan ancaman bencana. Risiko yang mungkin muncul diantaranya, kebakaran akibat terjadinya hubungan arus pendek atau konsleting pada peralatan elektronik yang tidak dimatikan.

Dewasa ini, penghematan energi listrik kurang diterapkan dalam kehidupan sehari-hari. Pasalnya, banyak pengguna peralatan elektronik menggunakan energi listrik secara berlebihan. Pemakaian secara berlebihan merupakan pemborosan yang dapat menyebabkan tingginya tagihan listrik yang harus dikeluarkan. Salah satu contoh penyebabnya yaitu terlupanya pengguna untuk mematikan peralatan tersebut ketika sedang tidak digunakan. Faktor lainnya yaitu unsur kesengajaan dari pengguna, hal ini dikarenakan kebanyakan pengguna merasa kesulitan dalam mengontrol penggunaan listrik yang harus dilakukan setiap waktunya.

Pemilik yang berpergian meninggalkan rumah atau tokonya dalam keadaan kosong, akan merasa tidak nyaman ketika ditengah perjalanan teringat belum mematikan peralatan elektronik seperti, kipas angin, AC (Air Conditioner), mesin pompa air listrik, atau sistem penerangan di waktu siang hari atau ketika peralatan-peralatan ini sedang tidak digunakan. Sehingga muncul berbagai kekhawatiran terjadinya hal yang tidak diinginkan terkait tagihan listrik ataupun resiko bencana. Ada pun becana yang sering dihadapi pada instalasi listrik rumah tinggal adalah hubungan singkat. Menurut (Kume, Lisi, \& Silimang, 2016) Dalam dunia ketenaga listrikan, seberapa besarnya gangguan hubung singkat yang bisa saja terjadi perlu diketahui sebelum gangguan sesungguhnya terjadi. Hal ini berguna unuk menentukan spesifikasi PMT, konduktor yang akan digunakan, Trafo, settingan Relay, dan lain-lain. Kendala bagi pemilik rumah atau toko, dimana hal yang dapat dilakukan hanyalah kembali untuk mematikan peralatan elektronik tersebut. Kendala akan semakin berat apabila jarak yang harus ditempuh cukup jauh serta memakan waktu dan biaya yang tidak sedikit.

Berdasarkan permasalahan yang diuraikan pada latar belakang masalah, maka perlu dibuat sebuah sistem pengontrolan yang dapat dimanfaatkan sebagai media kontrol jarak jauh. Sistem ini nantinya dapat memudahkan pengguna untuk melakukan pengontrolan menghidupkan dan mematikan peralatan listrik rumah tangga dari jarak jauh mengingat perkembangan teknologi jaringan komputer yang memungkinkan diterapkan kendali kontrol jarah jauh dengan memanfaatkan media atau infrastruktur jaringan internet yang sering disebut sebagai internet of thing sedangkan penelitian yang dilakukan oleh (Sentosa, Purwanto, Eng, \& Dikairono, 2016) memberikan kesimpulan Berdasarkan data yang diperoleh dari pengujian sistem,dapat disimpulkan bahwa kendali jarak jauh berbasis internet of things memiliki tingkat kehandalan yang tinggi yaitu sebesar $100 \%$. Dengan menggunakan spesifikasi sistem yang digunakan pada tugas akhir ini, robot servis dapat menjalankan seluruh perintah yang diinputkan oleh pengguna. Adapun model yang digunakan untuk kendali jarah jauh berbasis internet of thing adalah pemanfaatan teknologi protocol TCP/IP. Menurut penelitian yang dilakukan oleh(Nurul Hidayati dan Suwadi, 2016) ITS menggunakan protokol TCP. TCP mengoptimalkan pengiriman data yang akurat daripada ketepatan waktu.

\section{METODE PENELITIAN}

Agar penelitian ini lebih terarah maka dibuatkan framework penelitian yang ditunjukan pada gambar 1.1 sebagai berikut:

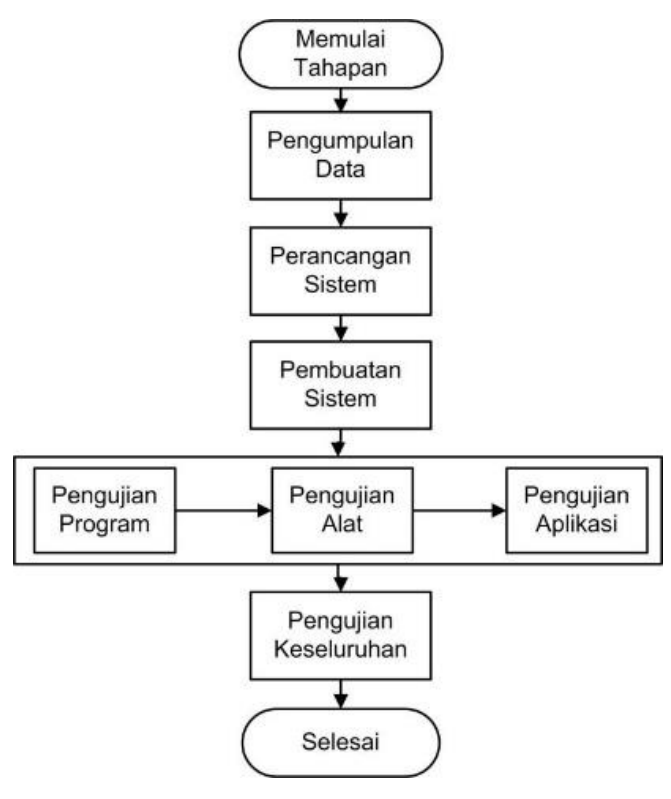




\section{Gambar 1.1 Framework Penelitian}

Penelitian ini dilakukan untuk sesuai dengan peningkatan modul ardhuino internet shield penelitian sebelumnya dilakukan oleh(safni marwa, 2013) kendali kontrol jarah jauh masih memanfaatkan port LPT atau port printer.

1. Pengumpulan data dilakukan analisis telah terjadinya update teknologi modul berbasis TCP/IP maka dibuat penelitian kendali jarak jauh menggunakan protocol TCP/IP tersebut.

2. Percangan dan pembuatan sistem meliputi proses pembuatan interface menggunakan bahasa pemogram scratch ardhuino dan bahasa pemrograman berbasis web.

3. Pengujian dilakukan apakah kendali kontrol jarak jauh menggunakan protocol TCP/IP memiliki jeda melalui perubahan dan pengiriman data.

4. Penelitian yang diharapkan bahwa kendali jarak jauh menggunakan protocol TCP/IP tidak memiliki jeda dan dapat berjalan sesuai dengan kendali yang diharapkan.

Adapun konsep penelitian kontrol berbasis TCP/IP ditunjukan pada gambar 1.2. Diagram blok sistem menggambarkan cara kerja dari sebuah sistem, dalam hal ini yaitu blok sistem kendali berbasis TCP/IP. Cara kerja dari penggunaan sistem kendali jarak jauh berbasis TCP/IP ini dapat dilihat pada gambar 1.2 sebagai berikut.

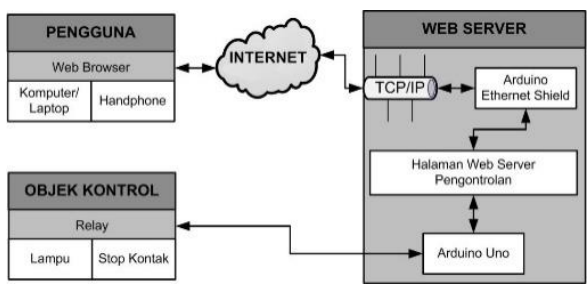

Gambar 1.2. Diagram Blok Sistem

Prisip kerja dari diagram blok yang ditunjukan pada gambar 1.2 adalah sebagai berikut :

1. Pengguna atau user dapat melakukan akses ke aplikasi melalui web browser

2. Komunikasi dilakukan antara komputer client dan komputer server menggunakan protocol TCP/IP, interface Modul TCP ip yang dimaksud adalah Ardhuino Ethernet Shield.

3. Modul ardhuino internet shield yang berhubungan langsung dengan I/O berupa relay, interface relay yang berhubungan langsung dengan device yang dikendalikan secara langsung.

4. Apabila terjadi perubahan data pada sisi client untuk mengubah sisi server maka device tersebut akan berubah pula kondisinya.

Miniatur rumah yang dibuat merupakan rancangan rumah sederhana dengan beberapa kamar dan ruangan. Denah rumah didesain untuk 2 kamar tidur dan 2 kamar mandi. Terdapat 1 ruang tamu dengan teras depan, sebuah dapur serta ruang keluarga yang ditunjukan pada gambar 1.2.

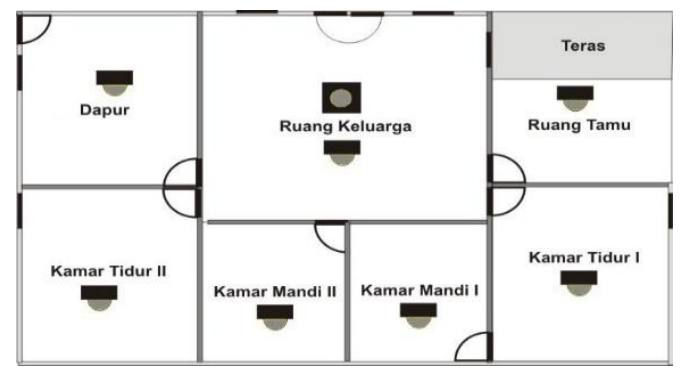

Gambar 1.2 Miniature Rumah

\section{HASIL DAN PEMBAHASAN}

Implementasi sistem berbentuk perangkat kendali yang dikendalikan dari sebuah halaman web. Pengguna cukup mengakses IP address web server dari perangkat, kemudian melakukan proses login sebelum dapat melakukan kontrol pada halaman kontrol. Pada implementasi sistem, halaman yang akan diakses oleh pengguna yaitu sebagai berikut.

1. Halaman Login

Halaman login merupakan halaman portal bagi user (pengguna) sebelum mengakses halaman kontrol lampu dan stop kontak. Halaman login ini akan muncul saat pertama kali mengakses alamat web server. Interface dari halaman login sebagai berikut. 


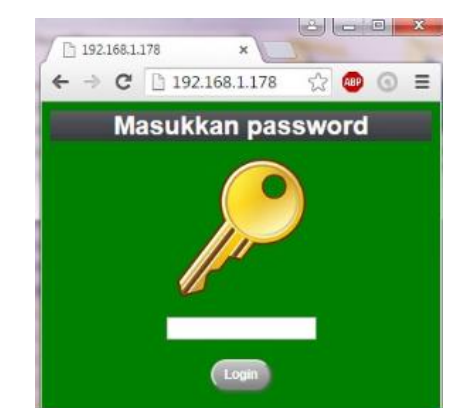

Gambar 1.3. Halaman Login

2. Halaman Kontrol

Halaman kontrol merupakan halaman berisikan tampilan lampu dan stop kontak yang akan dikontrol. Halaman ini berisikan keterangan nama peralatan listrik beserta tombol untuk menghidupkan atau mematikan. Interface halaman kontrol yaitu sebagai berikut.

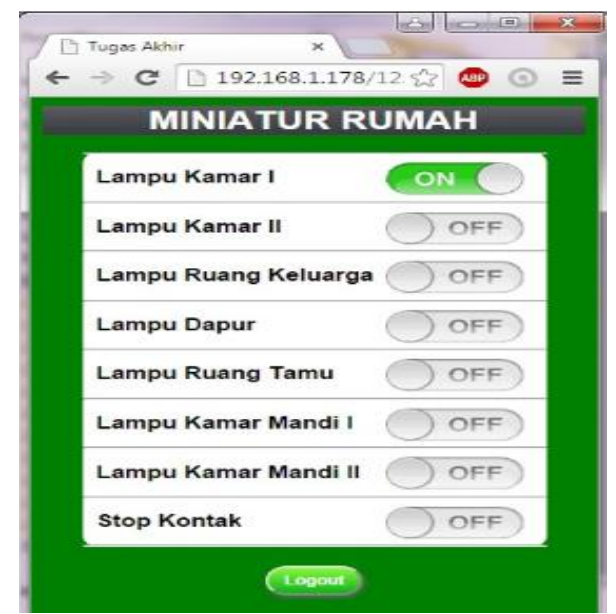

Gambar 1.4. Halaman Kontrol

\section{SIMPULAN DAN SARAN}

Dari penelitian yang telah dilakukan tentang pengendalian kontrol jarak jauh menggunakan protocol TCP/IP dan media jaringan internet maka dapat ditarik kesimpulan sebagai berikut:

1. Kendali kontrol berbasis $T C P / I P$ dapat memudahkan dalam mengendalikan peralatan peralatan elektronik rumah tangga dari jarak jauh.

2. Protocol TCP/IP dapat mengubah cara pengendalian yang biasa dilakukan dari dekat menjadi bisa dikendalikan dari mana saja dan kapan saja selama memiliki akses internet.

Adapun saran yang dapat dijadikan penelitian selanjutnya adalah aplikasi ini belum mempertimbangkan sistem keamanan (secure system).

\section{TERIMA KASIH}

Ucapan terima kasih di berikan kepada seluruh civitas akademika Universitas Muhammadiyah Riau (UMRI), yang telah memberikan dukungan moril dan materil terselengaranya penelitian ini.

\section{DAFTAR PUSTAKA}

Kume, J. T. I., Lisi, I. F., \& Silimang, S. (2016). Analisa Gangguan Hubung Singkat Saluran Kabel Bawah Tanah Tegangan $20 \mathrm{kV}$ Penyulang SL 3 GI Teling Manado. 5(4), 46-52.

Nurul Hidayati dan Suwadi. (2016). Analisis Kinerja TCP/IP untuk Jaringan Nirkabel Bergerak $3 G$ di Surabaya. 5(2).

safni marwa, sunanto. (2013). Aplikasi Kontrol Pemakaian Listrik Rumah Tangga Berbasis Web. Sawit Indonesia, 3(1), 23-31.

Sentosa, A., Purwanto, I. D., Eng, M., \& Dikairono, R. (2016). Rancang Bangun Kendali Jarak Jauh Robot Servis Berbasis Internet of Things. $5(2)$.

Wahid, A. (n.d.). Analisis kapasitas dan kebutuhan daya listrik untuk menghemat penggunaan energi listrik di fakultas teknik universitas tanjungpura. 